\title{
HRASLS Gene
}

National Cancer Institute

\section{Source}

National Cancer Institute. HRASLS Gene. NCI Thesaurus. Code C153056.

This gene plays a role in lipid acetylation and phospholipase activity. 